\title{
PENTINGNYA MEMBANGUN KOMITMEN KERJA SEBAGAI UPAYA MENINGKATKAN KINERJA MELALUI PENINGKATAN MOTIVASI, LINGKUNGAN, DAN KOMPENSASI
}

\author{
Fitria Nur Anggraeni \\ Universitas Islam Negeri Syarif Hidayatullah, Jakarta \\ Email : tahfizz@gmail.com
}

\begin{abstract}
ABSTRAK
Penelitian ini bertujuan untuk menganalisis dan membuktikan pengaruh kompensasi, disiplin kerja dan lingkungan kerja terhadap motivasi kerja, baik parsial maupun bersama-sama, dan pengaruh kompensasi, disiplin kerja, lingkungan kerja dan motivasi kerja terhadap komitmen organisasional, baik parsial maupun bersama-sama. Metode penelitian yang digunakan dalam penelitian ini adalah metode survey deskriptif dan survey eksplanatori dengan populasi sebayak 1.339 pegawai dan ukuran sampel sejumlah 224 responden, serta metode analisis data yang digunakan adalah SEM (Structural Equation Modeling). Berdasarkan hasil penelitian, maka didapatkan temuan struktur I, kompensasi dan lingkungan kerja secara parsial berpengaruh signifikan terhadap motivasi kerja, sedangkan disiplin kerja tidak berpengaruh signifikan, namun secara bersama-sama semua variabel eksogen berpengaruh positif dan signifikan terhadap motivasi kerja dengan nilai kontribusi $\left(R^{2}\right)$ sebesar $50 \%$. Secara parsial, variabel kompensasi paling dominan mempengaruhi motivasi kerja. Pada struktur II, kompensasi, disiplin kerja, lingkungan kerja dan motivasi kerja secara parsial dan bersamasama berpengaruh positif dan signifikan terhadap komitmen dosen dengan nilai kontribusi $\left(\mathrm{R}^{2}\right)$ sebesar $76 \%$. Secara parsial, variabel kompensasi paling dominan mempengaruhi komitmen dosen. Adapun motivasi kerja berperan sebagai partial mediating, di mana meningkatnya komitmen dosen dipengaruhi oleh kompensasi dan lingkungan kerja yang di mediasi oleh motivasi kerja. Sedangkan disiplin kerja dapat berpengaruh langsung terhadap komitmen dosen meski tidak termotivasi.
\end{abstract}

Kata Kunci : Komitmen, Lingkungan Kerja, Kompensasi, Motivasi

\begin{abstract}
This study aims to analyze and prove the effect of compensation, work discipline and work environment on work motivation, both partially and jointly, and the effect of compensation, work discipline, work environment and work motivation on organizational commitment, both partially and collectively. The research method used in this research is descriptive survey method and explanatory survey with a population of 1,339 employees and a sample size of 224 respondents, and the data analysis method used is SEM (Structural Equation Modeling). Based on the results of the study, then obtained the findings of structure I, compensation and work environment is partially significant effect on work motivation, while labor discipline no significant effect, but together all exogenous positive and significant effect on work motivation with the value of the contribution $\left(R^{2}\right)$ by $50 \%$. Partially, the compensation variable has the most dominant influence on work motivation. In the second structure, compensation, work discipline, work environment and work motivation partially and jointly positive and significant impact on faculty commitment to the value of the contribution $\left(R^{2)}\right.$ equal to $76 \%$. Partially, the compensation variable has the most dominant influence on lecturer commitment. The work motivation plays a role as partial mediating, where the increase in lecturer commitment is influenced by compensation and the work environment is mediated by work motivation. Meanwhile, work discipline can have a direct effect on lecturer commitment even though they are not motivated..
\end{abstract}

Keywords: Commitment, Environment, Compensation, Motivation 


\section{PENDAHULUAN}

Universitas sebagai salah satu penyelenggara pendidikan dan merupakan jenjang tertinggi, tentunya memiliki tugas yang berat untuk menghantarkan putra putri bangsa yang berdaya saing unggul, berbudaya dan berkarakter. Oleh karenanya, perguruan tinggi hendaknya mempertimbangkan aspek kualitas pendidikan yang berorientasi pada pembentukan karakter, keilmuan dan keahlian yang matang. Salah satu upaya yang dilakukan oleh perguruan tinggi adalah dengan melaksanakan Tri Darma perguruan Tinggi (Pendidikan, Penelitian dan Pengabdian kepada masyarakat) dengan sebaik-baiknya.

Sejalan dengan paparan di atas, kondisi pendidikan di Provinsi Banten sangat memprihatinkan, tidak hanya rendahnya pelaksanaan Tri Darma Perguruan Tinggi, akan tetapi masih banyak permasalahan lain misalnya, masih rendahnya tingkat pendidikan dosen, meski terdapat PTN dan PTS sejumlah 306 Perguruan Tinggi (forlap.dikti.go.id/ diakses pada 21-04-2017).

Banyaknya perguruan tinggi, namun tidak diimbangi dengan tenaga pengajar yang profesional. Di mana para dosen secara sinergi melaksanakan Tri Darma Perguruan Tinggi dengan kontinu. Padahal jika melihat pada rasio dosen di wilayah Kopertis IV Provinsi Banten cukup banyak yakni berjumlah 4,683 dosen (forlap.dikti.go.id/ diakses pada 21-04-2017).

Senyatanya banyaknya jumlah pengajar belum dapat memberikan arti yang signifikan terhadap kualitas pendidikan di Propinsi Banten sebagaimana data BPS tahun 2014, mengemukakan bahwa Indeks Pembangunan Manusia Propinsi Banten berada pada urutan ke 17 jauh dibandingkan dengan Propinsi Riau yang berada pada urutan 3, Kalimantan Timur urutan 5 dan Kalimantan Tengah pada peringkat 6. Permasalahan ini tidak terlepas dari tingkat pendidikan tenaga pengajar sebagai representatif dari kompetensi dan profesionalitas yang dimiliki dosen-dosen di Propinsi Banten.

Melihat permasalahan di atas tidak dapat dipandang sebelah mata, perlu ada tindakan nyata dari berbagai pihak, khususnya lembaga pendidikan tinggi dalam hal ini adalah universitas swasta di wilayah Kopertis IV Prov. Banten. Memang tidak dapat dipungkiri salah satu diduga kuat lahirnya permasalahan tersebut diakibatkan, karena rendahnya komitmen tenaga pengajar (dosen). Jika sebuah pendidikan merupakan representatif dari kemajuan sebuah Bangsa, maka orang kedua setelah pemerintah yang bertanggung jawab terhadap mutu dan kualitas SDM adalah tenaga pengajar dalam hal ini dosen.

Oleh karenanya para dosen harus secara sadar memahami akan peran dan fungsinya sebagai agen perubahan yakni melalui pendidikan yang maksimal, pelaksanaan penelitian dalam upaya memecahkan masalah-masalah publik dan pengabdian kepada masyarakat dalam rangka mencerdaskan kehidupan bangsa.

Sebagaimana masalah tersebut di atas, Melihat pada data Kemendikbud nampak terlihat cukup banyaknya jumlah universitas di Provinsi Banten, ini berarti menunjukkan cukup banyak populasi pendidikan Banten (11.83 juta) dan SDM Banten memiliki partisipasi yang cukup baik terhadap dunia pendidikan.

Data pada PDDIKTI nampak jelas pemasalahannya, di mana terjadi ketimpangan antara jumlah mahasiswa dengan jumlah dosen dengan rata-rata rasio 1:51. Artinya, lembaga pendidikan terkesan mengabaikan aturan dan ketentuan pendidikan yang 
seharusnya. Di mana penyelenggaraan pendidikan bermutu salah satunya harus memperhatikan aspek keseimbangan antara jumlah peserta didik dan jumlah tenaga pengajar (1:30 untuk Prodi Eksakta dan 1:45 untuk Prodi Sosial). Tentunya hal ini menggambarkan kondisi pendidikan yang kurang kondusif dan tidak berorientasi pada pendidikan berkualitas.

Permasalahan ini, tidak hanya pada jumlah rasio saja. Justru masalah sesungguhnya adalah rendahnya komitmen dosen, sebagai dampak membludaknya jumlah mahasiswa, yang pada akhirnya siapa saja asalkan tamatan S2, tanpa diperhatikan apakah linear atau tidak, apakah mumpuni pada bidang ilmu tertentu atau tidak, maka ia dapat jadi tenaga pengajar.

Lebih lanjut pada tabel di atas memperlihatkan informasi terkait kepangkatan dosen, di mana dosen tanpa kepangkatan sebanyak 168, Asisten Ahli sebanyak 1339 dosen, Lektor 44 dosen, Lektor Kepala 18 dosen dan Guru Besar 4 dosen. Data ini menjelaskan mayoritas dosen di Universitas Swasta Wilayah Kopertis IV di Provinsi Banten adalah berpangkat Asisten Ahli sedangkan dosen yang berpangkat Lektor, Lektor Kepala dan Guru Besar sangat minim. Tentunya ini mengisyaratkan bahwa banyaknya dosen yang berpangkat AA menunjukkan minimnya komitmen dan kesadaran dosen dalam menjalankan Tri Darma Perguruan Tinggi terutama penelitian dan pengabdian, mengingat syarat utama untuk mencapai kepangkatan adalah penelitian dan pengabdian masyarakat.

Kondisi di atas tentunya memberikan penjelasan bahwa para dosen di Universitas Wilayah Kopertis IV Prov. Banten belum memiliki komitmen kerja yang baik sebagai tenaga pengajar yang mengedepankan profesionalitas dan integritas, mengingat dosen adalah tenaga profesional independen yang dengan sendirinya dan kehendaknya bisa pindah atau berhenti kapan pun menjadi dosen.

Fenomena tidak aktifnya dosen salah satunya diakibatkan karena memiliki pekerjaan lain (double job). Hasil wawancara dengan sebagian dosen mengemukakan, banyak dosen yang mengajar di berbagai perguruan tinggi lain, sebahagiannya mengajar di sekolahan, ada yang menjadi pegawai swasta, ada yang menjadi wira usaha dan ada yang berstatus PNS. Ironisnya bahkan sebahagian dosen tetap, justru menganggap bahwa profesi dosen adalah pekerjaan sampingan, sedangkan pekerjaan utamanya adalah profesi lain (pegawai swasta, wiraswasta, PNS dan Guru).

Sangat jelas jika komitmen dosen rendah terhadap organisasi, mengingat pribadipribadi dosen yang tidak hanya memiliki satu pekerjaan saja, yang sudah barang tentu konsentrasi dan fokusnya bekerja akan terbagi-bagi dan justru akan cenderung berat sebelah, yakni para dosen akan lebih memprioritaskan pekerjaan yang memberikan jaminan kehidupan yang lebih layak.

\section{LANDASAN TEORI}

\section{Komitmen}

Terbentuknya kepercayaan dan loyalitas merupakan salah satu bentuk kepuasan karyawan terhadap organisasi yang menjadi harapan organisasi [1]. Setiap perusahaan selalu ingin memiliki karyawan yang berdedikasi pada organisasi, sehingga karyawan akan berusaha sekuat tenaga untuk mencapai tujuan perusahaan [2]. 
Penjelasan di atas biasanya mengartikan komitmen organisasi sebagai keyakinan pada tujuan, nilai, dan sikap untuk mempertahankan diri dalam organisasi [3]. Singkatnya, komitmen semacam ini adalah sikap bahwa orang bertindak sesuai dengan tujuan organisasi, seperti komitmen waktu, mengadakan rapat rutin, jika berhasil, maka luangkan beberapa menit untuk menunjukkan bahwa mereka peduli dengan kesuksesan mereka sendiri, sebaliknya, jika gagal, itu akan memakan banyak waktu, tolong bantu dia kembali ke jalur yang benar.

Dengan kata lain, definisi komitmen organisasi di atas adalah sikap yang mencerminkan kesetiaan karyawan kepada organisasi dan proses berkelanjutan di mana anggota organisasi mengungkapkan kepeduliannya terhadap organisasi dan keberhasilannya serta kemajuan yang berkelanjutan [4].

Secara teoritis komitmen terhadap organisasi melibatkan tiga sikap, yaitu identifikasi tujuan organisasi, rasa partisipasi dalam tugas organisasi, dan rasa loyalitas terhadap organisasi. Pekerjaan yang menjadi pekerjaannya dipahami sebagai keuntungan pribadi, dan keinginan untuk tetap setia pada kemajuan organisasi.

\section{Motivasi}

Intinya, pekerjaan seseorang selalu dilandasi oleh motivasi tertentu, yaitu motivasi. Motivasi menjadi kekuatan pendorong dan keinginan seseorang untuk menyelesaikan suatu tugas atau pekerjaan sesuai dengan yang diharapkan. Akan tetapi, motivasi itu sendiri tidak dapat dihasilkan dengan sendirinya, dan biasanya lingkungan eksternal menjadi salah satu faktor yang mengarah pada produksi motivasi internal seseorang. Sebagaimana dijelaskan Cecchini, motivasi harus memenuhi kebutuhan karyawan agar dapat beradaptasi dengan lingkungannya. Teori tersebut mensyaratkan bahwa motivasi bersifat dinamis sehubungan dengan kebutuhan yang diharapkan, dan semakin tinggi sejauh mana kebutuhan ini terpenuhi, semakin tinggi pula motivasinya [5]. Kepuasan kebutuhan hanya dapat disediakan oleh perusahaan sebagai faktor eksternal, yang dapat didorong dengan memberikan jaminan untuk memenuhi kebutuhan karyawan [6].

Pandangan lain dari Sugiarti, bahwa "motivasi mengacu pada proses yang memungkinkan upaya orang untuk dirangsang, dibimbing dan dipertahankan untuk mencapai tujuan" [7]. Di sini, motivasi diartikan sebagai proses di mana orang dapat melakukan upaya untuk membimbing dan mempertahankan pekerjaan mereka untuk mencapai tujuan. Jika setiap karyawan atau setiap karyawan dapat membangkitkan motivasi dalam setiap pelaksanaan pekerjaannya, maka realisasi tujuan perusahaan dan tujuan pribadi dalam organisasi akan tercapai secara maksimal. Artinya karyawan fokus pada apa yang harus mereka lakukan dan apa yang seharusnya menjadi faktor penting dalam mencapai tujuan mereka [8].

\section{Kompensasi}

Gaji merupakan indikator terpenting untuk meningkatkan kepuasan kerja dan meningkatkan produktivitas dan kinerja karyawan. Ini karena kompensasi menjadi alasan utama seseorang bekerja [9]. Namun dalam proses perkembangannya, karyawan juga akan memilih gaji yang dapat memenuhi kebutuhan hidup dan menentukan pilihan. Bahkan pada kelas manajemen seperti manajer atau direktur, kompensasi bagi mereka tidak hanya sebagai sarana finansial untuk menopang mata 
pencaharian mereka, tetapi kompensasi yang diharapkan harus dapat membuat mereka lebih bermakna dalam kehidupan sosial.

Tidak banyak industri yang menyadari hendak berartinya pemberian kompensasi yang layak untuk karyawan. Bukan lagi rahasia bila kompensasi yang baik serta berasaskan keadilan sanggup mendongkrak kinerja karyawan, tetapi masih terdapat organisasi di abad ini yang belum bisa membagikan kompensasi sebagaimana diharapkan, hingga tidak khayal banyak karyawan yang turnover untuk mencari industri lain yang bisa memberikan penghargaan lebih baik [10].

Kompensasi jadi alibi mendasar kenapa seorang ingin melaksanakan pekerjaan. Kompensasi sanggup memotivasi serta mendesak seorang buat tumbuh . Walaupun secara universal kompensasi bukan salah satunya yang melatar belakangi orang bekerja. Hendak namun tiap orang hendak merasa bahagia apalagi merasa puas bila diberi kompensasi yang bisa penuhi kebutuhan hidupnya. Sehingga dia hendak membalas dengan bekerja penuh semangat serta kinerja yang tinggi.

\section{Lingkungan Kerja}

Aspek kondisi kerap kali jadi orang bergairah ataupun kebalikannya malas bekerja, ikatan antar pegawai kerap kali jadi orang betah bekerja ataupun malah menjadikan orang kilat menyudahi kerja serta apalagi tidak tidak sering orang merasa tumbuh sebab dorongan pimpinan ataupun dapat jadi orang merasa tertekan dalam bekerja. Faktor- faktor tersebut merupakan area kerja [11]. Lebih lanjut, area kerja sangat mempengaruhi terhadap seseorang pegawai. Seluruh suatu baik bertabiat langsung ataupun tidak langsung baik yang berkaitan dengan pekerjaan ataupun yang bertabiat emosional sangat pengaruhi kondisi psikologis seorang.

Jelas kalau pekerjaan sangat bergantung dengan keadaan kejiwaan seseorang pegawai. Perasaan tertekan, tidak puas, area yang kurang kondusif jadi aspek tidak terduga oleh industri yang bisa mengganggu kinerja pegawai, terlebih pegawai hendak merasa malas serta tidak bergairah melaksanakan pekerjaan, yang pastinya ini sangat mempengaruhi terhadap hasil kerja yang diharapkan [12].

Para pakar mengemukakan, kalau area kerja selaku kekuatan- kekuatan yang bisa mempengaruhi, baik langsung ataupun tidak langsung terhadap kinerja organisasi. Maksudnya seorang hendak sanggup melakukan pekerjaannya dengan baik bila ditunjang oleh keadaan area kerja yang menunjang [13]. Semacam tersedianya fasilitas teknologi, peralatan kantor yang mendukung serta ikatan yang harmonis antar rekan kerja dan atasan.

Paparan tersebut mengisyaratkan, area kerja jadi motivasi eksternal yang mempunyai akibat besar terhadap semangat kerja pegawai. Area kerja dengan bermacam kelengkapan sarana kerja, perlengkapan pendukung serta ikatan antar pegawai dan pimpinan harmonis jadi aspek berarti buat melindungi kestabilan emosional pegawai, dengan demikian dia hendak menampilkan sikap positif serta merasa bahagia melaksanakan pekerja dan jadi bagian dari organisasi [14].

Riset yang sudah dicoba oleh Park \& Doo, meyakinkan kalau area kerja mempengaruhi signifikan terhadap motivasi kerja baik secara parsial ataupun secara bersama- sama dengan variabel lain [15]. Temuan ini menerangkan kalau area kerja jadi hawa ataupun suasana di dalam organisasi yang berkaitan dengan perasaan, sedangkan pekerjaan diperlukan terdapatnya emosional yang normal. Dengan kata 
lain, area kerja jadi aspek internal pegawai dalam melaksanakan tugas- tugasnya yang dipengaruhi oleh area dekat. Oleh karenanya, membangun area yang kondusif serta normal jadi perihal utama dalam menghasilkan daya guna bisnis di tiap guna manajemen [17]. Dengan demikian seluruh pegawai merasakan aman, yang pada kesimpulannya merasa puas dengan area yang menunjang, sehingga berimplikasi pada hasil kerja yang optimal. Lebih lanjut riset yang dicoba oleh Bai, et al. hasil penelitiannya menerangkan kalau area aspek lain yang susah buat diduga, tetapi akibatnya sangat signifikan, apalagi banyak pegawai yang tidak bisa bertahan disebabkan area yang tidak kondusif [18].

\section{METODE PENELITIAN}

Rancangan ataupun tata cara analisis merupakan bermacam perlengkapan analisis riset supaya rumusan permasalahan riset bisa terpecahkan, hipotesis riset bisa dibuktikan ataupun diuji, serta kesimpulannya tujuan riset bisa tercapai. Ada pula pendekatan tata cara riset yang digunakan merupakan tata cara kuantitatif. Kuantitatif ialah pendekatan riset bersumber pada bilangan angka dengan memakai statistik buat menanggapi persoalan hipotesis riset.

Berikutnya riset ini bertabiat deskriptif serta verifikatif. Riset deskriptif ialah pemaparan terhadap fenomena yang bersumber pada kenyataan serta informasi yang terdapat, tanpa bermaksud mengambil kesimpulan mendalam. Sebaliknya watak riset verifikatif ialah pengujian pembuktian terhadap hipotesis yang sudah dibentuk dengan perlengkapan statistik yang digunakan.

Sejalan dengan paparan di atas, maka metode yang digunakan adalah metode deskriptif survey dan metode explanatory survey, tipe investigasi penelitian ini adalah kausalitas dan unit analisis adalah individu, yaitu para dosen tetap universitas swasta wilayah Kopertis IV Prov. Banten, time horizon dalam penelitian ini adalah crossectoral, yaitu informasi dari sebagian populasi (sampel responden) dikumpulkan langsung dari lokasi secara empirik, dengan tujuan untuk mengetahui dari sebagian populasi terhadap objek yang diteliti.

Dalam penelitian ini metode analisis menggunakan structural equation modeling (SEM). Menurut ahli, apabila suatu model menggunakan lebih dari satu dependen variabel maka penyelesaian model menggunakan beberapa persamaan regresi menjadi tidak tepat. Teknik analisis lain dibutuhkan, yaitu model yang berbentuk struktur banyak dependen variabel yaitu structural equation modeling (SEM).

\section{HASIL PENELITIAN DAN PEMBAHASAN}

\section{Penilaian Responden Terhadap Fenomena Penelitian}

Kompensasi dosen Universitas Swasta di Wilayah Kopertis IV Prov. Banten memiliki rata-rata skor 757 dan total skor 10603. Adapun unsur kompensasi Universitas Swasta di Prov Banten yang paling besar skornya adalah pada unsur Dosen berprestasi dilibatkan dalam setiap kegiatan universitas yaitu sebesar 844 . Sedangkan unsur kompensasi Universitas Swasta di Prov Banten yang paling rendah skornya adalah Gaji yang diberikan layak dengan skor 627. Hal ini menunjukkan bahwa pada umumnya dosen telah mempersepsikan kompensasi baik terutama dalam unsur dilibatkannya dosen berprestasi dalam setiap kegiatan universitas. 
Namun demikian sebagian dosen mempersepsikan kompensasi Universitas Swasta Wilayah Kopertis IV Provinsi Banten masih kurang baik dalam hal pemberian gaji.

Lingkungan kerja memiliki rata-rata skor 691 dan total skor 8295. Adapun unsur lingkungan kerja yang paling besar skornya adalah Akrab dengan rekan kerja yaitu sebesar 761. Sedangkan unsur lingkungan kerja yang paling rendah skornya adalah Tersedia jaringan internet dengan skor 556. Hal ini menunjukkan bahwa pada umumnya dosen telah mempersepsikan baik lingkungan kerja dalam hal keakraban antar dosen. Namun demikian lingkungan kerja dipersepsikan kurang baik dalam hal ketersediaan jaringan internet.

Motivasi kerja dosen memiliki rata-rata skor 729 dan total skor 10213. Adapun unsur motivasi kerja dosen yang paling besar skornya adalah pada Semangat untuk bekerjasama yaitu sebesar 828 . Sedangkan unsur motivasi kerja dosen yang paling rendah skornya adalah Semangat untuk mengikuti ujian kepangkatan dengan skor 622. Hal ini menunjukkan bahwa secara keseluruhan para dosen mempersepsikan motivasi kerja dalam hal semangat bekerja sama sudah baik. Namun motivasi kerja dosen dalam hal semangat untuk mengikuti ujian kepangkatan masih rendah. Data di atas menjelaskan, faktanya para dosen memiliki motivasi yang tinggi dalam hal kerjasama. Hal ini terjadi karena tingginya intensitas pertemuan antar dosen, misalnya pada saat jam istirahat para dosen berkumpul di ruang dosen, sudah barang tentu akan terjadi interaksi yang pada akhirnya terbentuk ikatan emosional. Dengan kata lain, para dosen akan lebih mudah untuk bekerja sama antara satu dengan yang lain, mengingat antar pribadi dosen sudah saling kenal dan bahkan dekat. Beberapa di antara kerja sama yang biasa dilakukan adalah menyusun modul, silabus atau soal ujian. Bahkan tidak hanya itu, banyak dosen yang kemudian saling mendukung atau saling membantu, misalnya dalam hal tugas-tugas penelitian dan pengabdian. Di mana dosen saling bertukar informasi dan berbagi pengalaman.

Komitmen dosen memiliki rata-rata skor 722 dan total skor 11554. Adapun unsur komitmen dosen yang paling besar skornya adalah Bangga menjadi bagian organisasi (perguruan tinggi) yaitu sebesar 885. Sedangkan unsur komitmen dosen yang paling rendah skornya adalah Memiliki kesamaan tujuan dengan perguruan tinggi dengan skor 578. Hal ini menunjukkan bahwa pada umumnya komitmen dosen sudah baik dalam hal kebanggaan menjadi bagian dari perguruan tinggi (dosen). Namun komitmen dosen dalam hal keselarasan tujuan dengan perguruan tinggi masih rendah.

Temuan ini menjelaskan, bahwa faktanya dosen baru dapat berkomitmen berdasarkan kebanggaannya menjadi seorang dosen. Di mana menyandang status sebagai tenaga pengajar di suatu perguruan tinggi adalah kebanggaan tersendiri, sehingga kecenderungan komitmen yang terbentuk adalah sebatas menjaga statusnya atau keanggotaannya. Kondisi ini adalah suatu keadaan wajar atau alamiahnya seorang manusia, dengan menyandang statis tinggi, maka dosen tersebut akan lebih dihargai, dikenal dan akui oleh masyarakat. Bahwa tidak jarang menyandang status Dosen di lingkungan provinsi Banten adalah suatu profesi yang baik, karena dianggap sebagai orang berpendidikan tinggi yang memiliki pengetahuan luas. Sedangkan komitmen dosen dalam hal kesamaan tujuan dengan perguruan tinggi masih rendah, faktanya universitas tidak dapat memberikan jaminan bahwa setiap dosen yang bergabung menjadi dosen tetap akan memperoleh masa depan 
yang baik, kondisi ini yang menyebabkan tidak selarasnya tujuan individu dosen dengan universitas.

\section{Analisis SEM Struktur Kesatu}

Berdasarkan olah data menggunakan Lisrel, maka untuk uji hipotesis secara parsial, variabel Kompensasi dengan nilai $t_{\text {hitung }}=5.77>t_{\text {kritis }}=1.96$, variabel, dan variabel Lingkungan kerja dengan nilai $t_{\text {hitung }}=2.98>t_{\text {kritis }}=1.96$. Sementara secara bersama-sama variabel Kompensasi dan Lingkungan kerja dengan nilai $F_{\text {hitung }}=47.91$ $>F_{\text {kritis }}=3.41$.

Keputusan dari uji hipotesis adalah:

1. Hipotesis kesatu $(\mathbf{H 1}): \mathbf{H}_{0}$ ditolak dan $\mathbf{H}_{\mathbf{a}}$ diterima, artinya Kompensasi berpengaruh positif dan signifikan secara parsial terhadap Motivasi kerja

2. Hipotesis kedua $(\mathrm{H} 2): \mathbf{H}_{0}$ ditolak dan $\mathbf{H}_{\mathbf{a}}$ diterima, artinya Lingkungan kerja berpengaruh positif dan signifikan secara parsial terhadap Motivasi kerja.

3. Hipotesis ketiga $(\mathrm{H} 3): \mathbf{H}_{0}$ ditolak dan $\mathbf{H}_{\mathbf{a}}$ diterima, artinya Kompensasi dan Lingkungan kerja berpengaruh positif dan signifikan secara bersama-sama terhadap Motivasi kerja.

Kompensasi berpengaruh signifikan terhadap Motivasi kerja, artinya semakin baik Kompensasi dipersepsi oleh dosen, maka semakin tinggi Motivasi kerja dosen Universitas Swasta Wilayah Kopertis IV di Provinsi Banten. Adapun besar pengaruh Kompensasi secara parsial terhadap Motivasi kerja adalah sebesar 0,83. Demikian juga Lingkungan kerja berpengaruh terhadap motivasi kerja, artinya semakin baik Lingkungan kerja di kampus, maka semakin meningkatkan Motivasi kerja dosen, sebesar 0,30. Kemudian Kompensasi, Disiplin kerja, dan lingkungan kerja secara bersama-sama berpengaruh signifikan terhadap Motivasi kerja. Berarti bahwa semakin baik Kompensasi dipersepsi oleh dosen, semakin tinggi Disiplin kerja dan semakin baik lingkungan kerja, maka akan semakin meningkatkan Motivasi kerja dosen. Adapun besar kontribusi pengaruh Kompensasi dan lingkungan kerja secara bersamasama terhadap Motivasi kerja adalah sebesar $50 \%\left(R^{2}=0,50\right)$, sementara besarnya pengaruh faktor lain yang tidak diteliti sebesar $50 \%$, seperti sarana dan prasarana, penghargaan, kompetensi, atau kinerja. Secara parsial, kompensasi berpengaruh dominan terhadap motivasi kerja.

Hasil analisis di atas memperkuat dan mengonfirmasi teori, bahwa kompensasi, lingkungan kerja baik sendiri-sendiri maupun bersama-sama dengan variabel lain berpengaruh signifikan terhadap motivasi kerja. Temuan ini menjelaskan pemberian kompensasi yang berkeadilan, mampu memenuhi harapan, dan ditetapkannya sebuah aturan kedisiplinan serta terbentuknya sebuah lingkungan kerja yang kondusif akan meningkatkan motivasi kerja yang teraplikasikan dalam bentuk semangat kerja, taat kepada kebijakan organisasi dan terjalinnya hubungan kerja antar pegawai dan antar pimpinan yang saling menghargai, yang pada akhirnya akan terakumulasi menjadi komitmen organisasi secara keseluruhan. Jadi secara simultan sejalan dengan hasil penelitian ini. Namun pada penelitian ini justru kompensasi faktor yang paling penting dalam meningkatkan motivasi kerja dosen. Hal ini sejalan dengan hasil analisis pada penelitian ini.

\section{Analisis SEM Struktur Kedua}

Berdasarkan olah data, maka untuk uji hipotesis secara parsial, Kompensasi dengan nilai $t_{\text {hitung }}=2.87>t_{\text {kritis }}=1.96$, variabel Lingkungan kerja dengan nilai $t_{\text {hitung }}$ 
$=2.18>t_{\text {kritis }}=1.96$, dan variabel Motivasi kerja dengan nilai $t_{\text {hitung }}=3.08>t_{\text {kritis }}=1.96$. Sementara secara bersama-sama variabel Kompensasi, Lingkungan kerja, dan Motivasi kerja dengan nilai $F_{\text {hitung }}=67.52>F_{\text {kritis }}=3.41$.

Keputusan dari uji hipotesis adalah:

1. Hipotesis keempat $(\mathrm{H} 4): \mathbf{H}_{0}$ ditolak dan $\mathbf{H}_{\mathbf{a}}$ diterima, artinya Kompensasi berpengaruh positif dan signifikan secara parsial terhadap Komitmen dosen

2. Hipotesis kelima $(\mathbf{H} 5): \mathbf{H}_{0}$ ditolak dan $\mathbf{H}_{\mathbf{a}}$ diterima, artinya Lingkungan kerja berpengaruh positif dan signifikan secara parsial terhadap Komitmen dosen.

3. Hipotesis keenam ( $(\mathbf{6} 6): \mathbf{H}_{0}$ ditolak dan $\mathbf{H}_{\mathbf{a}}$ diterima, artinya Motivasi kerja berpengaruh positif dan signifikan secara parsial terhadap Komitmen dosen .

4. Hipotesis ketujuh (H7): $\mathbf{H}_{0}$ ditolak dan $\mathbf{H}_{\mathbf{a}}$ diterima, artinya Kompensasi, Lingkungan kerja, dan Motivasi kerja berpengaruh positif dan signifikan secara bersama-sama terhadap Komitmen dosen.

Kompensasi berpengaruh positif dan signifikan terhadap Komitmen dosen, artinya semakin baik kompensasi yang diberikan, maka dapat meningkatkan komitmen dosen. Disiplin kerja berpengaruh positif dan signifikan terhadap Komitmen dosen, artinya semakin tinggi kesadaran dosen untuk mematuhi aturan disiplin kerja yang berlaku maka dapat meningkatkan komitmen dosen. Lingkungan kerja berpengaruh positif dan signifikan terhadap komitmen dosen, artinya semakin baik lingkungan kerja, maka dapat meningkatkan komitmen dosen. Motivasi kerja berpengaruh positif dan signifikan terhadap komitmen dosen, artinya semakin baik motivasi kerja, maka dapat meningkatkan komitmen dosen. Kemudian kompensasi, disiplin kerja, lingkungan kerja, dan motivasi kerja secara bersama-sama berpengaruh signifikan terhadap komitmen dosen. Artinya kompensasi yang baik dengan ditunjang oleh disiplin kerja yang tinggi dan didukung dengan adanya lingkungan kerja yang kondusif, maka dapat meningkatkan motivasi kerja, sehingga berimplikasi pada meningkatnya komitmen dosen pada Universitas Swasta Wilayah Kopertis IV di Provinsi Banten. Adapun besar kontribusi pengaruh kompensasi, disiplin kerja, lingkungan kerja, dan motivasi kerja secara bersama-sama terhadap komitmen dosen adalah sebesar $76 \%\left(R^{2}=0,76\right)$, sementara besarnya pengaruh faktor lain yang tidak diteliti sebesar $24 \%$ kemungkinan disebabkan oleh sarana dan prasarana, penghargaan, kompetensi, atau kinerja. Secara parsial, kompensasi berpengaruh dominan terhadap komitmen dosen.

\section{Temuan Penelitian}

Hasil temuan ini bermakna peningkatan kompensasi terutama dimensi kompensasi non finansial yang didukung oleh didukung dengan peningkatan lingkungan kerja terutama hubungan dengan rekan kerja dapat meningkatkan motivasi kerja dosen terutama motivasi berafiliasi yang implikasinya dapat meningkatkan komitmen dosen terutama komitmen afektif.

Pengaruh langsung kompensasi terhadap komitmen dosen adalah sebesar $0.33^{2}$ $(0,1089)$, sedangkan pengaruh tidak langsung melalui motivasi kerja adalah sebesar $0,83 \times 0,26=0,2158$. Hal ini menunjukkan bahwa kompensasi dapat meningkatkan komitmen apabila dosen termotivasi.

Pengaruh langsung lingkungan kerja terhadap komitmen dosen adalah sebesar $0.15^{2}(0,0225)$, sedangkan pengaruh tidak langsung melalui motivasi kerja sebesar $0,30 \times 0,26=0,078$. Hal ini menunjukkan bahwa lingkungan kerja dapat meningkatkan komitmen apabila dosen termotivasi. 
Berdasarkan kedua analisis di atas, dapat dikatakan bahwa motivasi kerja berperan sebagai partial mediating, di mana meningkatnya komitmen dosen dipengaruhi oleh kompensasi dan lingkungan kerja yang di mediasi oleh motivasi kerja. Sedangkan disiplin kerja dapat berpengaruh langsung terhadap komitmen dosen meski tidak termotivasi.

\section{KESIMPULAN DAN SARAN}

Berdasarkan uraian hasil pengujian hipotesis penelitian di atas, maka temuan pada penelitian ini adalah bahwa Komitmen dosen yang direfleksikan oleh dimensi Komitmen afektif dan dibentuk oleh indikator Bangga dengan keanggotaannya dalam organisasi pada Universitas Swasta Wilayah Kopertis IV di Provinsi Banten akan meningkat, apabila Motivasi kerja meningkat yang direfleksikan oleh dimensi Kebutuhan berafiliasi dan dibentuk oleh indikator Semangat untuk bekerja sama, kemudian didukung dengan peningkatan Kompensasi yang direfleksikan oleh dimensi Kompensasi non finansial dan dibentuk oleh indikator Penghargaan, dan didukung dengan peningkatan Lingkungan kerja yang direfleksikan oleh dimensi Hubungan dengan rekan kerja dan dibangun oleh indikator mudah bergaul.

Berdasarkan hasil analisis, ternyata inti masalahnya adalah "dosen kurang bangga dengan keanggotaannya dalam perguruan tinggi ", sedangkan solusinya adalah:

1. Tingkatkan motivasi kerja dalam berafiliasi, yaitu berupa semangat untuk bekerja sama,

2. Tingkatkan kompensasi non finansial, yaitu berupa penghargaan terhadap dosen, misalnya dengan melibatkan dalam setiap kegiatan organisasi (pengajaran, penelitian, pengabdian, seminar, workshop atau penghargaan kinerja dan masa bakti),

3. Perbaiki lingkungan kerja, yaitu dengan mendorong agar tercipta suatu interaksi atau pergaulan antar dosen yang aktif (saling mengenal, saling sapa, saling berkomunikasi, saling berinteraksi)

\section{DAFTAR PUSTAKA}

[1] Harras, H., Sugiarti, E., \& Wahyudi, W. (2020). Kajian Manajemen Sumber Daya Manusia Untuk Mahasiswa.

[2] Wahyu, W., \& Salam, R. (2020). KOMITMEN ORGANISASI (Kajian: Manajemen Sumber Daya Manusia).

[3] Wahyudi, M. (2019). PENGARUH DISIPLIN DAN MOTIVASI TERHADAP KINERJA KARYAWAN. SCIENTIFIC JOURNAL OF REFLECTION: EConomic, Accounting, Management and Business, 2(3), 351-360.

[4] PAAIS, M., \& PATTIRUHU, J. R. (2020). Effect of motivation, leadership, and organizational culture on satisfaction and employee performance. The Journal of Asian Finance, Economics, and Business, 7(8), 577-588.

[5] Cecchini, J. A., Fernandez-Rio, J., Mendez-Gimenez, A., Gonzalez, C., SanchezMartínez, B., \& Carriedo, A. (2020). High versus low-structured cooperative learning. Effects on prospective teachers' regulation dominance, motivation, content knowledge and responsibility. European Journal of Teacher Education, 116.

[6] Wahyudi, W. (2018). The Influence Of Job Satisfaction And Work Experience On Lecturer Performance Of Pamulang University. SCIENTIFIC JOURNAL OF 
REFLECTION: Economic, Accounting, Management and Business, 1(2), 221-230.

[7] Sugiarti, E. (2018). Building Work Commitment of Bppt Employee. SCIENTIFIC JOURNAL OF REFLECTION: Economic, Accounting, Management and Business, 1(2), 171-180.

[8] Mukrodi, M. (2018). The Commitment Analysis Of Religion Ministry In Banten Province. SCIENTIFIC JOURNAL OF REFLECTION: Economic, Accounting, Management and Business, 1(2), 161-170.

[9] Jabbar, M. N., Hussin, F., Hashmi, M. A., \& Jafri, S. M. I. (2020). Effect of Administrative Practices on Job Performance: An Empirical Study among Public University Employees in Pakistan. Global Academic Journal of Economics and Business, 1(1), 1-4.

[10] Mukrodi, M. (2019). Membangun Motivasis Kerja. SCIENTIFIC JOURNAL OF REFLECTION: Economic, Accounting, Management and Business, 2(4), 431-440.

[11] Smith, D., \& Rhiney, E. (2020). CSR commitments, perceptions of hypocrisy, and recovery. International Journal of Corporate Social Responsibility, 5(1), 1-12.

[12] Joarder, M. H. R., \& Ashraf, A. (2020). Quality Education from Faculty Management Perspectives in Private Higher Education: Does Faculty Commitment Behaviour Mediate?. International Journal of Education and Practice, 8(1), 190-206.

[13] Saridakis, G., Lai, Y., Muñoz Torres, R. I., \& Gourlay, S. (2020). Exploring the relationship between job satisfaction and organizational commitment: an instrumental variable approach. The International Journal of Human Resource Management, 31(13), 1739-1769.

[14] Fajri, C., Rahman, Y. T., \& Wahyudi, W. (2021). MEMBANGUN KINERJA MELALUI LINGKUNGAN KONDUSIF, PEMBERIAN MOTIVASI DAN PROPORSIONAL BEBAN KERJA. SCIENTIFIC JOURNAL OF REFLECTION: Economic, Accounting, Management and Business, 4(1), 211-220.

[15] Park, S., \& Doo, M. Y. (2020). The effect of organizational culture and HR practices on female managers' commitment and job satisfaction. European Journal of Training and Development.

[16] Bai, Z., Luo, S., Zhang, L., Wu, S., \& Chi, I. (2020). Acceptance and commitment therapy (ACT) to reduce depression: $A$ systematic review and meta-analysis. Journal of Affective Disorders, 260, 728-737.

[17] Wahyudi, W. (2018). The Influence of Emotional Intelligence, Competence and Work Environment on Teacher Performance of SMP Kemala Bhayangkari Jakarta. SCIENTIFIC JOURNAL OF REFLECTION: Economic, Accounting, Management and Business, 1(2), 211-220.

[18] Khalid, K. (2020). The Impact of Managerial Support on the Association Between Pay Satisfaction, Continuance and Affective Commitment, and Employee Task Performance. SAGE Open, 10(1), 2158244020914591. 